\title{
LAPORAN PENGAMATAN \& EVALUASI \\ IMPLEMENTASI SISTEM KESELAMATAN \\ DAN KESEHATAN KERJA PT. YUASA BATTERY INDONESIA \\ TANGERANG-BANTEN
}

Oleh: Harjoyo, SE, MM.

harjoyo@yuasabattery.co.id

\begin{abstract}
Abstrak
Penulisan ini bertujuan untuk mengetahui kebijakan dan strategi perusahaan dalam melakukan perlindungan diri pekerja dari kecelakaan yang mungkin terjadi di tempat kerja. Dalam melakukan implementasi kebijakan, perusahaan dengan atau tanpa tekanan pemerintah harus tetap memperhatikan tingkat keselamatan kerja karyawannya demi tercapainya tingkat produktivitas yang tinggi. Upaya perusahaan dalam hal ini adalah dengan membuat konsep dan penerapan Sistem Keselamatan dan Kesehatan Kerja di wilayah perusahaan yang diterapkan di semua level dengan tujuan untuk memaksimalkan hasil yang hendak dicapai.

Dari Hasil penelitan ini disarankan tambahan alat guna mendeteksi gejala dini bila terjadi kebakaran di wilayah kerja serta pengadaan seorang ahli K3 yang disahkan Instansi yang berwenang sebagai legalisasi tenaga terampil dalam menerapkan SMK3. Disarankan pula untuk melakukan kerjasama dalam bentuk latihan K3 gabungan dengan tetangga terdekat perusahaan yang notabene sebuah SPBU yang mempunyai risiko sangat tinggi.
\end{abstract}

Kata kunci: K3 (Keselamatan \& Kesehatan Kerja), risiko kecelakaan, pengamanan

\section{PENDAHULUAN}

\section{Latar Belakang Masalah}

Di era globalisasi sekarang ini menuntut pelaksanaan Keselamatan dan Kesehatan Kerja (K3) di setiap sektor usaha atau pekerjaan dengan tujuan menekan serendah mungkin resiko kecelakaan dan atau penyakit akibat kerja (PAK), serta meningkatkan produktivitas.

Kecelakaan yang terjadi di lingkungan kerja tidak hanya disebabkan karena kelalaian dari para pekerja saja, melainkan juga dapat disebabkan dari peralatan yang digunakan saat bekerja. Karena kurangnya kesadaran dan pengetahuan para pekerja untuk menggunakan alat pelindung diri (APD), menyebabkan banyak terjadinya kecelakaan di 
lingkungan kerja. Kecelakaan yang terjadi dapat menghambat atau mengganggu proses produksi dan menurunkan citra perusahaan.

Accident Proneness adalah kenyataan, bahwa untuk pekerja-pekerja tertentu terdapat tanda-tanda kecenderungan untuk mengalami kecelakaan. Di sini jelas betapa pentingnya faktor manusia dalam terjadinya kecelakaan akibat kerja. Memang ada orangorang yang bersifat sembrono, asal saja, suka melamun, dan lain-lain, sehingga mereka mempunyai kecenderungan untuk celaka. Seorang pekerja yang terlalu lamban tidak sesuai untuk pekerjaan yang memerlukan kegesitan, bisa membuat dia celaka. Begitu juga bila tergesa-gesa, pekerja demikian apa kemungkinan terjatuh atau mengalami kecelakaan lalu-lintas.

Kecelakaan terjadi tanpa diduga sebelumnya dan dalam sekejap mata, dan setiap kejadian terdapat 4 faktor yang bergerak dalam satu kesatuan berantai yaitu lingkungan, bahaya, peralatan, dan manusia. Kecelakaan akibat kerja adalah kecelakaan yang berkaitan dengan hubungan kerja pada perusahaan. Hubungan kerja di sini dapat berarti, bahwa kecelakaan terjadi dikarenakan oleh pekerjaan atau pada waktu melaksanakan pekerjaan. Kadang-kadang kecelakaan akibat kerja diperluas ruang lingkupnya, sehingga juga meliputi kecelakaan-kecelakaan tenaga kerja yang terjadi pada saat perjalanan atau transportasi ke dan dari tempat kerja. Bahaya pekerjaan adalah faktor-faktor yang dapat mendatangkan kecelakaan. Bahaya tersebut disebut potensial, jika faktor-faktor tersebut belum mendatangkan kecelakaan. Jika kecelakaan telah terjadi, maka bahaya tersebut adalah sebagai bahaya nyata.

Perusahaan dalam salah satu usaha meminimalisasi bahkan sebagai upaya preventif terjadinya kecelakaan kerja dan atau penyakit akibat kerja (PAK) adalah dengan menerapkan Sistem Keselamatan dan Kesehatan Kerja.

\section{Identifikasi Masalah}

Identifikasi masalah dalam penulisan ini adalah:

1. Adakah tekanan dari pemerintah terhadap Perusahaan dalam bentuk himbauan atau edaran tentang perlunya pelaksanaan Sistem Keselamatan dan Kesehatan Kerja untuk melindungi pekerja maupun perusahaan itu sendiri dari rasa tidak aman, nyaman, dan bahaya kecelakaam kerja dan atau sakit akibat kerja? 
2. Perlukah adanya suatu sistem dalam organisasi yang mempunyai tanggung jawab terhadap pelatihan K3 di setiap level dan posisi untuk meningkatkan kesadaran K3 pada seluruh karyawan?

3. Adakah hambatan dalam implementasi Sistem Keselamatan dan Kesehatan Kerja dari karyawan, karena akan merubah kebiasaan yang selama ini berjalan menjadi kebiasaan yang mengacu pada penaatan aturan seperti penggunaan alat pelindung diri, membuang sampah sesuai jenisnya (apakah masuk kategori B3 atau Non B3, dsb.)?

4. Apakah setelah dilaksanakannya Sistem Keselamatan dan Kesehatan Kerja di PT. Yuasa Battery Indonesia, karyawan sudah merasa cukup aman dan nyaman dalam bekerja? Apakah pelaksanaan Sistem Keselamatan dan Kesehatan Kerja cukup efektif, dilihat dari angka kecelakaan kerjanya?

5. Perlukah diberikan pelatihan yang khusus kepada karyawan yang bekerja di lokasi kerja yang memiliki potensi bahaya yang tinggi selain pelatihan $\mathrm{K} 3$ yang diberikan secara umum kepada seluruh karyawan?

\section{Pembatasan Masalah}

Dari identifikasi bahasan, penulis membuat pembatasan masalah yang berkaitan dengan:

1. Kebijakan dan strategi perusahaan dalam membangun sistem Sistem Keselamatan dan Kesehatan Kerja di PT. Yuasa Battery Indonesia

2. Implementasi Konsep Sistem Keselamatan dan Kesehatan Kerja serta pelaksanaannya di PT. Yuasa Battery Indonesia

3. Hasil yang diperoleh setelah dilaksanakannya Sistem Keselamatan dan Kesehatan Kerja di PT. Yuasa Battery Indonesia

\section{Rumusan Masalah}

Setelah melakukan analisa dan penelitian, penulis membuat rumusan masalah sebagai berikut:

1. Bagaimana proses produksi baterei di PT. Yuasa Battery Indonesia?

2. Bagaimana konsep dan penerapan Sistem Manajemen Keselamatan dan Kesehatan Kerja di wilayah PT. Yuasa Battery Indonesia?

3. Apa manfaat yang diperoleh setelah menerapkan Sistem Manajemen Keselamatan dan Kesehatan Kerja? 


\section{Tujuan Penulisan}

Maksud dari penulisan ini adalah untuk mengetahui pengaruh atau efektivitas setelah diberlakukan Sistem Keselamatan dan Kesehatan Kerja di PT. Yuasa Battery Indonesia.

Tujuan umum dari penulisan ini adalah :

1. Untuk mengetahui proses produksi baterei di PT. Yuasa Battery Indonesia agar dapat mengatasi kecelakaan kerja terhadap pekerja di wilayah pabrik.

2. Mengetahui konsep dan penerapan Sistem Keselamatan dan Kesehatan Kerja di wilayah PT. Yuasa Battery Indonesia.

3. Untuk mengetahui manfaat yang diperoleh setelah menerapkan Sistem Keselamatan dan Kesehatan Kerja.

Penulisan ini diharapkan dapat menjadi nilai tambah bagi PT. Yuasa Battery Indonesia, sehingga pekerja merasa lebih diperhatikan akan hak-hak keselamatan dan kesehatan kerjanya dan mampu meningkatkan produktivitas yang tentu saja akan sangat menguntungkan perusahaan.

\section{Manfaat Penulisan}

Hasil penelitian ini diharapkan dapat bermanfaat bagi semua pihak yang terkait utamanya bagi pihak-pihak berikut ini :

1. Bagi Tim P2K3, sarana untuk mengambil inisiatif dalam rangka penyempurnaan implementasi Sistem Keselamatan dan Kesehatan Kerja sehingga target dan sasaran bahwa semakin baiknya atau minimnya angka kecelakaan kerja atau sakit akibat kerja/zero accident akan tercapai.

2. Bagi perusahaan sebagai bahan masukan dalam mengambil kebijaksanaan yang tepat dan memberikan/menambah sarana dan prasarana dalam rangka memberikan gairah dalam rangka memberikan perlindungan rasa aman dan nyaman terhadap pekerjanya, sehingga suasana kerja kondusif dan produktivitaas akan meningkat.

3. Bagi Penulis Sebagai bahan latihan dalam penulisan karya ilmiah, sekaligus sebagai tambahan informasi untuk mengembangkan program K3 yang menjadi pekerjaan sehari-hari penulis sehingga bisa memberikan kontribusi yang positip untuk perusahaan. 


\section{Deskripsi Teoritik}

Sistem Manajemen K3 adalah bagian dari sistem manajemen perusahaan secara keseluruhan yang dibutuhkan bagi pengembangan, penerapan, pencapaian, pengkajian dan pemeliharaan kewajiban $\mathrm{K} 3$, dalam rangka pengendalian resiko yang berkaitan dengan kegiatan kerja guna terciptanya tempat kerja yang aman, efisien, dan produktif.

\section{Pengertian Keselamatan dan Kesehatan Kerja}

Menurut M. Sulaksmono (1997) kecelakaan adalah “ Suatu kejadian tak diduga dan tidak dikehendaki yang mengacaukan proses suatu aktifitas yang telah diatur”. Kecelakaan terjadi tanpa disangka-sangka dan dalam sekejap mata, dan setiap kejadian menurut Benneth Silalahi (1995) terdapat empat faktor yang bergerak dalam satu kesatuan yang berantai yaitu lingkungan, bahaya, peralatan, dan manusia. Kecelakaan akibat kerja adalah kecelakaan yang berhubungan dengan hubungan kerja pada perusahaan. Bahaya pekerjaan adalah faktor-faktor dalam hubungan pekerjaan yang dapat mendatangkan kecelakaan. Bahaya tersebut disebut potensial, jika faktor-faktor tersebut belum mendatangkan kecelakaan. Jika kecelakaan terjadi, maka bahaya tersebut adalah sebagai bahaya nyata.

Kecelakaan-kecelakaan di rumah atau rekreasi atau cuti, dan lain-lain adalah diluar makna kecelakaan akibat kerja, sekalipun pencegahannya sering dimasukkan kedalam program keselamatan perusahaan. Kadang-kadang kecelakaan akibat kerja diperluas ruang lingkupnya, sehingga juga meliputi kecelakaan-kecelakaan tenaga kerja yang terjadi pada saat perjalanan atau transport ke dan dari tempat kerja. Kecelakaankecelakaan demikian termasuk kepada kecelakaan umum hanya saja menimpa tenaga kerja diluar pekerjaannya.

Secara umum penyebab kecelakaan ada dua, yaitu unsafe action (faktor manusia) dan unsafe condition (faktor lingkungan). Menurut penelitian bahwa $80 \sim 85 \%$ kecelakaan disebabkan oleh unsafe condition. Unsafe action dapat disebabkan oleh ketidakseimbangan fisik tenaga kerja yaitu, posisi tubuh yang mudah lemah, cacat fisik, cacat sementara, kepekaan panca indra terhadap sesuatu, kurang pendidikan, menjalankan pekerjaan tanpa mempunyai kewenangan, menjalankan pekerjaan yang tidak sesuai dengan keahliannya, pemakaian alat pelindung diri (APD) hanya berpurapura, mengangkut beban yang berlebihan, bekerja berlebihan atau melebihi jam kerja. Dan unsafe condition dapat disebabkan oleh peralatan yang sudah tidak layak pakai, ada api di tempat bahaya, pengamanan gedung yang kurang standar, terpapar bising, 
pencahayaan dan ventilasi yang kurang atau berlebihan, sistem peringatan yang berlebihan, sifat pekerjaan yang mengandung bahaya.

Kondisi bangunan adalah tempat atau bangunan yang digunakan untuk tempat bekerja apakah telah memenuhi criteria keselamatan bagi penghuni bangunan tersebut. Kondisi mesin yang ada di perusahaan juga harus baik, sehingga harus ada penjadwalan perawatan mesin-mesin untuk proses produksi. Hal ini bertujuan untuk mencegah kerusakan mesin yang dapat membahayakan operator.

Tujuan pelaksanaan program keselamatan dan kesehatan kerja menurut pasal 3 ayat 1 UUD no. 1 tahun 1970 adalah :

- Mencegah dan mengurangi kecelakaan.

- Mencegah, mengurangi, dan memadamkan kebakaran.

- Mencegah dan mengurangi bahaya peledakan.

- Memberi kesempatan atau jalan menyelamatkan diri pada waktu kebakaran atau kejadian-kejadian lain yang berbahaya.

- Memberikan pertolongan pada kecelakaan.

- Memberi alat-alat pelindung diri.

- Mencegah dan mengendalikan timbulnya penyakit akibat kerja, baik fisik maupun psikis, peracunan, infeksi dan penularan.

- Memperoleh penerangan yang cukup dan sesuai.

- Menyelenggarakan suhu dan kelembaban yang cukup.

- Memelihara kebersihan, kesehatan, dan ketertiban.

- Memperoleh keserasian antara tenaga kerja, alat kerja, lingkungan, cara dan proses kerjanya.

- Mengamankan dan memperlancar pengangkutan orang, binatang, tanaman, atau batang.

- Mengamankan dan memelihara jenis bangunan.

- Mengamankan dan memperlancar kerja bongkar muat, perlakuan dan penyimpanan barang.

- Mencegah terkena aliran listrik yang berbahaya.

- Menyesuaiakan dan menyempurnakan pengamanan pada pekerjaan yang berbahaya kecelakaannya bertambah tinggi.

Kesehatan kerja adalah spesialisasi dalam ilmu kesehatan / kedokteran besertaprakteknya yang bertujuan agar pekerja atau masyarakat pekerja memperoleh 
derajat kesehatan setinggi-tingginya, baik fisik, mental, maupun social. Dengan usahausaha preventif dan kuratif, terhadap penyakit-penyakit/gangguan-gangguan kesehatan yang diakibatkan faktor-faktor pekerjaan dan lingkungan kerja, serta terhadap penyakit-penyakit umum (Suma'mur 1993:1).

Definisi kesehatan adalah kondisi umum fisik, mental, dan stabilitas emosi secara umum. Sedangkan individu yang sehat adalah yang bebas penyakit, cedera, serta masalah mental dan emosi yang bisa mengganggu aktivitas manusia normal umumnya. Adapun faktor-faktor yang dapat menyebabkan kesehatan kerja terganggu adalah sebagai berikut :

1. Faktor fisik, meliputi :

a. Bunyi dan getaran yang bisa menyebabkan ketulian atau pekak (sementara atau permanen)

b. Suhu ruang kerja, suhu yang tinggi dapat menyebabkan hyperprexia, heat stroke, dan heat cramp, (keadaan-keadaan panas badan yang tinggi suhunya). Sedangkan suhu yang rendah sekali (di bawah $0^{\circ} \mathrm{C}$ ) dapat menyebabkan kekakuan dan keradangan akibat dingin.

c. Radiasi sinar rontgen atau sinar-sinar radioaktif yang menyebabkan kelainan pada kulit, mata, bahkan susunan darah.

d. Tekanan udara yang tinggi menyebabkan ketulian permanen, caisson disssease (keadaan ditandai dengan kelumpuhan, rasa sakit karena panas udara), dan lainlain.

2. Faktor kimia, mencakup :

a. Debu dan serbuk.

\section{Manajemen Keselamatan dan Kesehatan Kerja}

Manajemen sebagai satu ilmu yang mencakup aspek sosial dan eksak tidak terlepas dari tanggung jawab keselamatan dan kesehatan kerja, baik dari segi perencanaan maupun pengambilan keputusan dan organisasi.

Manajemen seharusnya menyadari (Silalahi,MPH,1995) :

1. Adanya biaya pencegahan.

2. Kerugian akibat kecelakaan yang menimpa karyawan dan peralatan.

3. Antara biaya pencegahan dan kerugian akibat kecelakaan terdapat selisih yang sukar ditetapkan.

4. Kecelakaan kerja selalu menyangkut manusia, peralatan, dan proses. 
5. Manusia merupakan faktor dominan dalam setiap kecelakaan.

Sistem Manajemen K3 adalah bagian dari sistem manajemen perusahaan secara keseluruhan yang dibutuhkan bagi pengembangan, penerapan, pencapaian, pengkajian dan pemeliharaan kewajiban $\mathrm{K} 3$, dalam rangka pengendalian resiko yang berkaitan dengan kegiatan kerja guna terciptanya tempat kerja yang aman, efisien, dan produktif.

\section{METODOLOGI PENELITIAN}

\section{Lokasi dan Waktu Penelitian}

Penelitian dilakukan di tempat kerja penulis, PT. Yuasa Battery Indonesia, yang berlokasi di Jl. MH. Thamrin No.1, Kebon Nanas Tangerang. Waktu pelaksanaan dari tanggal 20 Pebruari 06 Maret 2012.

\section{Jenis Penelitian}

Penelitian ini menggunakan Metode Kualitatif. Tujuan utama penelitian kualitatif adalah untuk memahami (to understand) fenomena atau gejala sosial dengan lebih menitik beratkan pada gambaran yang lengkap tentang fenomena yang dikaji daripada memerincinya menjadi variabel-variabel yang saling terkait.

\section{Populasi dan Sampel}

Dari data yang diperoleh setelah implementasi Sistem Keselamatan dan Kesehatan Kerja PT. YUASA BATTERY INDONESIA ditemukan data sebagai berikut:

Tabel 1 Presentasi Kecelakaan Kerja PT. YUASA BATTERY INDONESIA

\begin{tabular}{|c|c|c|c|c|c|c|c|}
\hline Tahun & 2006 & 2007 & 2008 & 2009 & $2010 *$ & $2011^{*}$ & $\sim$ Peb $2012 *$ \\
\hline $\begin{array}{c}\text { Kecelakaan } \\
\text { Kerja }\end{array}$ & 22 & 18 & 20 & 10 & 5 & 4 & 0 \\
\hline $\begin{array}{c}\text { Jumlah } \\
\text { Tenaga kerja } \\
\%\end{array}$ & 1212 & 1243 & 1299 & 1411 & 1462 & 1500 & 1526 \\
\hline$\%$
\end{tabular}

Tanda * = Sudah implementasi Sistem Keselamatan dan Kesehatan Kerja

Sumber: Dokumen P2K3 PT Yuasa Battery Indonesia 
Penulis mengambil sampel dari jumlah total pekerja PT. Yuasa Battery Indonesia dari tahun ke tahun, dan ditemukan populasi yang signifikan, sebelum \& sesudah implementasi Sistem Keselamatan dan Kesehatan Kerja oleh perusahaan.

\section{Variabel Penelitian (Definisi Teoritik dan Operasional)}

Variabel adalah entitas/kesatuan apapun, yang memiliki nilai yang berbeda/ bervariasi. Apapun dapat disebut sebagai variabel, asal ia punya nilai yang beragam (vary, variate, bervariasi).

Definisi lain, bahwa variabel adalah "any factor that can take on different values". Variabel adalah semua faktor yang dapat mempunyai nilai yang berbeda. Adapun variabel itu ada 2 jenis yaitu variabel bebas (independent), dan variabel terikat (dependent).

Dalam penulisan ini menggunakan tiga variabel yaitu :

1. Support dan dukungan Manajemen terhadap K3 (variabel terikat/dependent).

2. Implementasi Sistem Keselamatan dan Kesehatan Kerja(variabel bebas/independent).

3. Implikasi Sistem Keselamatan dan Kesehatan Kerja bagi karyawan dan perusahaan (variabel terikat/dependent).

\section{Metode Pengumpulan Data}

Metode pengumpulan data yang penulis pergunakan dalam penyusunan laporan ini adalah sebagai berikut:

\section{Metode Observasi}

Metode observasi adalah suatu teknik untuk memperoleh data dengan menggunkan pengamatan (gejala-gejala) yang diselidiki. Berdasarkan pendapatpendapat dapat dikemukakan bahwa Observasi adalah merupakan tekhnik atau metode untuk mengadakan penelitian dengan cara mengamati langsung terhadap kejadian, baik di sekolah maupun di luar sekolah dan hasilnya dicatat secara sempurna. Dengan metode ini peneliti mengadakan pengamatan secara langsung terhadap obyek penelitian, dalam hal ini yang diamati adalah lokasi atau letak penelitian.. Dari sana dapat diketahui beberapa data yang dibutuhkan dalam kegiatan penelitian ini.

\section{Metode Interview}

Metode ini disebut juga dengan wawancara adalah sebuah dialog yang dilakukan oleh pewawancara untuk memperoleh informasi dari terwawancara. Dalam penelitian ini penulis menggunakan metode wawancara yang bersifat tidak langsung, yaitu 
wawancara yang dilakukan dengan karyawan dan pihak yang mewakili manajemen perusahaan.

\section{Metode Dokumentasi}

Metode dokumentasi adalah mencari data mengenai hal-hal atau variabel yang berupa catatan transkrip, agenda dan sebagainya. Peneliti menggunakan metode ini adalah untuk memperoleh data tentang angka kecelakaan kerja di PT. Yuasa Battery Indonesia dari tahun ke tahun.

4. Metode Analisa Data

Setelah mengadakan serangkaian kegiatan (penelitian) dengan menggunakan beberapa metode di atas, maka data-data yang terkumpul dianalisa dengan menggunakan teknik deskriptif. Teknik ini dipergunakan untuk menganalisa data yang bersifat kualitatif atau data yang tidak dapat direalisasikan dengan angka. Adapun data yang bersifat kuantitatif akan dianalisa dengan menggunakan teknik prosentase.

Dalam laporan ini penulis menggunakan Metode Analisa Data berupa Data Statistik, karena menurut penulis, dengan menggunakan statistik, data dapat diolah dengan lebih eksak. Dengan statistik mungkin pula dapat mengungkapkan aspek-aspek baru, sehingga dapat memancing pemahaman baru yang dapat membantu menelaah permasalahan yang dihadapi.

\section{PEMBAHASAN DAN HASIL ANALISA}

\section{Implementasi Sistem Keselamatan dan Kesehatan Kerja PT. Yuasa Battery Indonesia}

Untuk merealisasikan tujuan Sistem Keselamatan dan Kesehatan Kerja sesuai dengan UU No. 1 tahun 1970 yang mengatur tentang Keselamatan Kerja dan Peraturan Menteri Tenaga Kerja No. 05 tahun 1996 tentang Sistem Manajemen Keselamatan dan Kesehatan Kerja (SMK3), Pada tahun 2009 dilakukan penyempurnaan Struktur Organisasi P2K3. Wujud dari dukungan Top Manajemen terhadap perlunya dilaksanakan Sistem Manajemen Keselamatan dan Kesehatan Kerja tersebut bisa dilihat dengan 
dengan dikeluarkannya Surat Keputusan (SK) pembentukan susunan pengurus P2K3 (Panitia Pembina Keselamatan \& Kesehatan Kerja). ..(Lampiran 1) Untuk menciptakan rasa aman dan nyaman pekerja serta upaya meminimalisir bahaya menghindari terjadinya kecelakaan kerja, P2K3 sebagai badan yang bertanggung jawab untuk hal tersebut membuat program kegiatan, seperti pengadaan alat tanggap darurat, identifikasi potensi dan sumber bahaya, serta sosialisasi penggunaan alat pelindung diri (APD) secara benar.

\section{Proses Produksi baterai}

Secara umum proses kegiatan produksi di PT. Yuasa Battery Indonesia terdapat dua pelaksanaan produksi, yaitu pembuatan lead acid battery dry charge atau baterai kering dan pembuatan lead acid battery wet charge atau baterai basah. Bagian/ tempat pembuatan bubuk timah hitam (lead powder), bahan baku yang digunakan adalah timah hitam murni (pure lead 99,99 \%) dan O2. Proses pembuatannya berdasarkan reaksi oksidasi, cairan timah hitam dipanaskan pada suhu $400^{\circ} \mathrm{C}$, cairan tersebut dialirkan melalui pompa ke cetakan dan dipotong-potong, kemudian dibawa melalui bucket elevator ke drum (yang berputar dengan temperature $185^{\circ} \mathrm{C}$ ) dimasukkan udara dari luar melalui reacting blower maka terjadilah reaksi menjadi serbuk timah hitam. Grid Casting bagian pembuatan rangka pelat (grid) aki, proses pembuatannya dilakukan dengan mengalirkan cairan timah hitam $\left(400^{\circ} \mathrm{C}\right)$ kedalam cetakan (mold) kemudian didinginkan dan akhirnya diperoleh rangka pelat aki. Bahan bakunya yaitu paduan timah hitam antimoni (lead antimony allow) dengan kadar antimony sebesar 2,5\%.

Part Casting section adalah bagian pembuatan pole/ terminal aki. Proses pembuatannya dilakukan dengan menuangkan cairan timah hitam $\left(400^{\circ} \mathrm{C}\right)$ kedalam cetakan (mold) kemudian didinginkan dan akhirnya diperoleh pole dan terminal aki. Bagian pembuatan pelat aki terbagi menjadi 4 bagian yaitu : paste mixing atau pembuatan pasta yang bahan-bahannnya terdiri dari bubuk timah hitam, asam sulfat, air murni, dan bahan tambahan lainnya. Campuran bahan-bahan tersebut diaduk sedemikan rupa dengan mixer selama waktu tertentu sehingga akhirnya diperoleh pasta. Setelah pasta dibuat, lalu dilakukan proses pelapisan terhadap rangka pelat aki dengan pasta dan menggunakan mesin khusus sehingga dihasilkan pelat aki.

Surface Drying adalah pelat aki yang selesai dibuat, permukaannya dikeringkan terlebih dahulu dengan menggunakan oven. Curing pada tahap ini, pelat aki dikeringkan lagi di dalam satu ruangan khusus yang kondisi suhu/kelembaban udaranya diatur konstan. 
Proses pengeringan berlangsung 2 3 kali selama 24 jam. Drying setelah dari ruangan khusus, pelat-pelat aki menjalani proses pengeringan terakhir di udara terbuka selama 3 4 hari.

Formation adalah bagian pengisian (charging) pelat-pelat aki sehingga bermuatan listrik. Pada tahap ini diperoleh aki yang mempunyai pelat positip (berwarna coklat) dan pelat negatip (berwarna abu-abu). Proses Formation adalah pengisian yang dilakukan dengan menggunakan arus listrik DC yang bersumber dari unit rectifier selama 20 jam.

Besarnya arus listrik yang diberikan tergantung pada macam/tipe pelat aki yang diproduksi. Washing setelah pelat aki selesai diisi, selanjutnya pelat aki harus dicuci terlebih dahulu untuk menghilangkan sisa-sisa asam sulfat yang masih menempel. Drying pada bagian pelat aki yang telah dicuci dikeringkan dengan menggunakan mesin pengering pada suhu $130^{\circ} \mathrm{C}$ untuk pelat negatip dan $60 \sim 80^{\circ} \mathrm{C}$ untuk pelat positif selama 2 3 jam. Cutting adalah bagian pekerjaan yang melakukan pemotongan pelat-pelat aki yang berupa panel-panel menggunakan mesin. Potongan disesuaikan dengan tipe aki yang akan diproduksi. Pemotongan dilakukan apabila pelat-pelat aki telah memenuhi syarat kualitas yang telah ditetapkan yaitu kapsitas, appearance, dan sebagainya. Setelah proses assembling (perakitan ) yang terdiri dari :

1. Stacking : Proses penyusunan pelat aki (negatip \& positip ) yang dibatasi/ disekat oleh separator (diafragma).

2. Burning : Proses penyambungan pelat-pelat aki yang mempunyai polaritas yang sama yaitu positip dengan positip, negatip dengan negatip, dengan cara pengelasan sehingga diperoleh hasil menjadi group pelat.

3. Inserting : Proses memasukkan group pelat kedalam bak aki atau istilah yang lazim container sesuai dengan kedudukan sel-selnya.

4. TTP Machine : proses penyambungan sel konektor aki masing-masing sel yang sudah disusun dalam bak (container) menggunakan pengelasan listrik.

5. Heat Seal Machine : Proses perekatan antara bak aki (yang sudah berisi sel-sel yang tersambung) dengan lid cover melalui pemanasan agar tidak terjadi kebocoran

6. Finishing : Proses akhir yang meliputi pembersihan, pemeriksaan, pemberian aksesoris dan pengepakan 

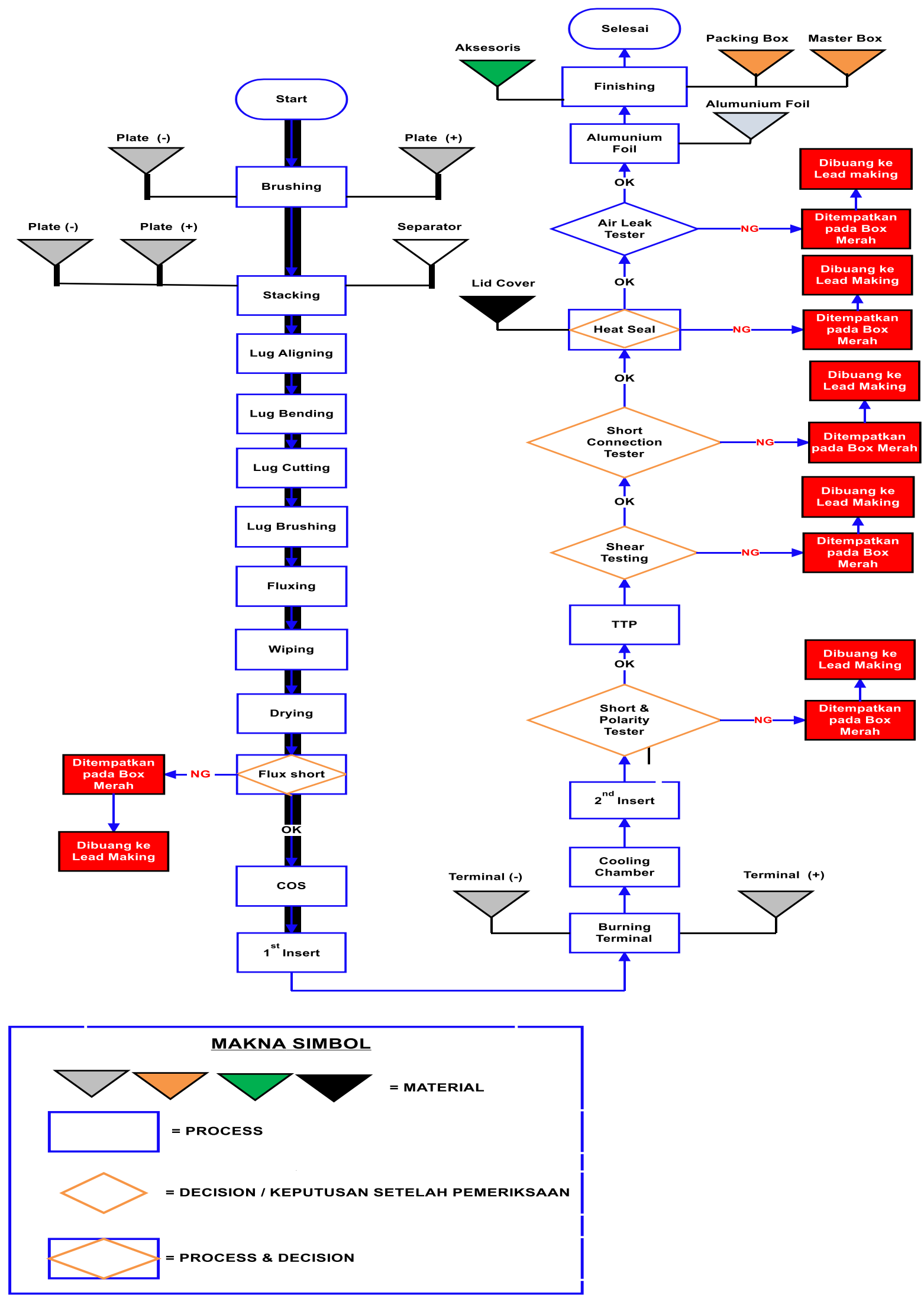

Gambar 1. Diagram Alur Proses Pembuatan Aki/ Lead Acid Battery

Sumber: Data Sekunder 


\section{Prasarana dan Sarana Lingkungan}

Sarana dan prasarana lingkungan PT. Yuasa Battery Indonesia sangat diperhatikan, hal ini ditunjukkan dengan adanya pemantauan berkala. Sarana dan prasarana yang dipantau antara lain :

\section{Air Bersih}

Sumber air bersih di PT. Yuasa Battery Indonesia dari air tanah atau sumur dalam. Peruntukannya untuk cuci tangan, toilet, pembersihan lantai, cuci alat di dapur, kantor, dan lain-lain.

2. Air Limbah

Pengelolaan air limbah disalurkan ke Instalasi Pengolahan Air Limbah (IPAL) kemudian diolah di WWT (Waste Water Threatment) setelah itu air limbahnya yang sudah diproses di WWT diambil sampelnya untuk diuji di laboratorium UNILAB. Jika sudah memenuhi baku mutu setelah itu baru dibuang ke sungai. Untuk pemeriksaan air limbahnya dilakukan setiap hari, dan untuk pengambilan sampel diuji setiap satu bulan sekali.
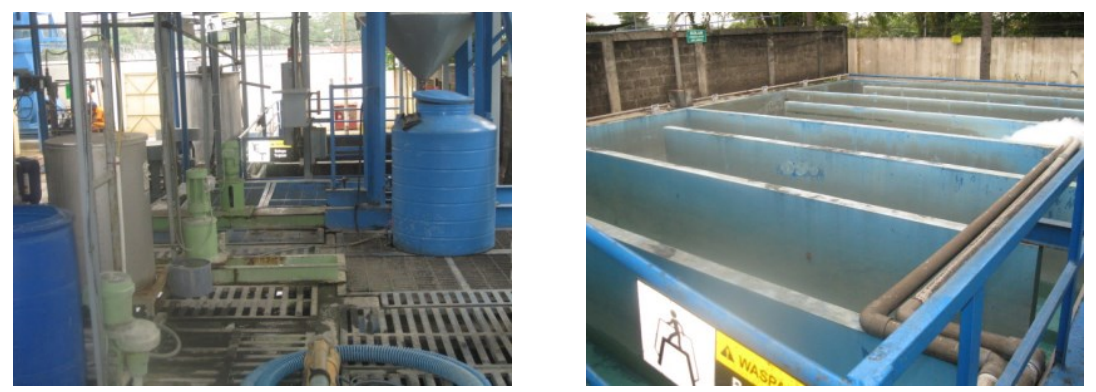

Gambar 2. Pengolahan Air Limbah (WWT)

3. Sampah

Pengelolaan sampah dibagi menjadi tiga klasifikasi atau kategori, yaitu :

a. Sampah organik menggunakan trash bin atau tong sampah berwarna kuning. Sampah organik diangkut ke TPS Rawa Kucing, Tangerang.

b. Sampah non organik menggunakan trash bin atau gerobak sampah berwarna kuning, terdapat dus-dus bekas atau box bekas yang masih ada nilai ekonomisnya dapat dijual kembali.

c. Sampah B3 menggunakan tong sampah berwarna merah. Sampah B3 ini nantinya akan disimpan di gudang B3 dan diangkut oleh PT. NFU setiap 2 hari sekali. 

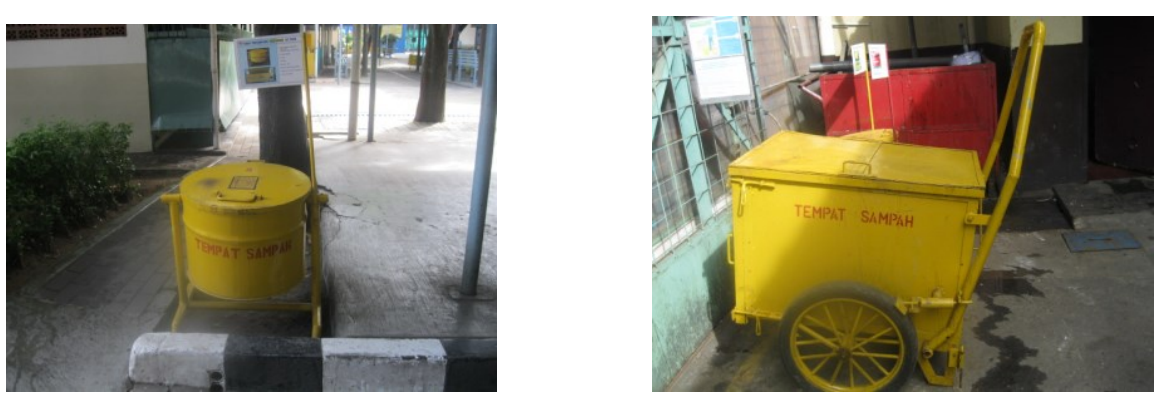

Gambar 3. Tong Sampah Non B3

Sumber: Data Primer
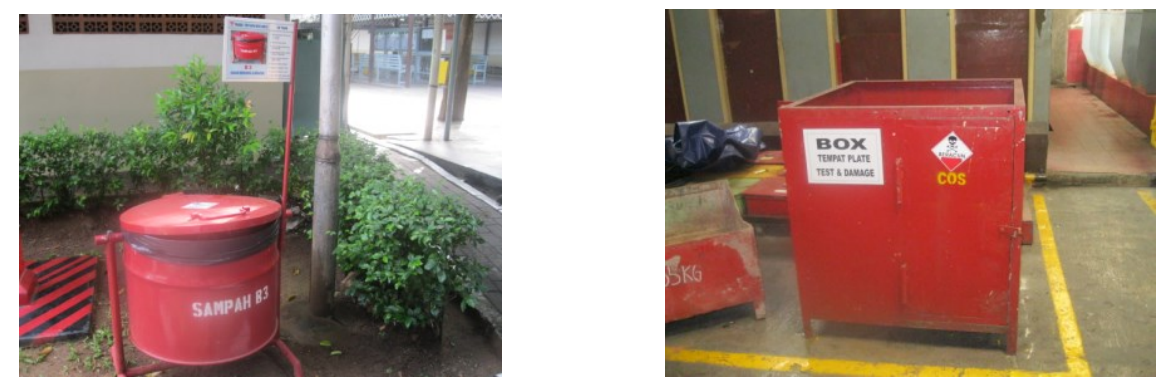

\section{Gambar 4. Tong Sampah B3}

Sumber: Data Primer

\section{Drainese/Pembuangan}

Sistem drainese terbagi 2 klasifikasi, yaitu :

a. Saluran untuk air limbah produksi disalurkan ke WWT (Waste Water Threatment) dengan jalur warna merah.

b. Saluran air non limbah seperti air hujan, air dari kamar mandi/ toilet, air sisa kegiatan kantin dengan jalur warna hijau akan disalurkan ke sungai.

\section{Perlengkapan Alat Tanggap Darurat :}

Tabel 2 : Data Peralatan Tanggap Darurat PT. Yuasa Battery Indonesia

\begin{tabular}{|l|l|c|c|c|}
\hline No. & \multicolumn{1}{|c|}{ Nama Alat } & Gambar & Jumlah & \multicolumn{1}{|c|}{ Keterangan } \\
\hline 1 & APAR (Alat & & 157 buah & Terpasang di \\
& Pemadam Api & seluruh area \\
& Ringan) & & & pabrik \\
\hline
\end{tabular}




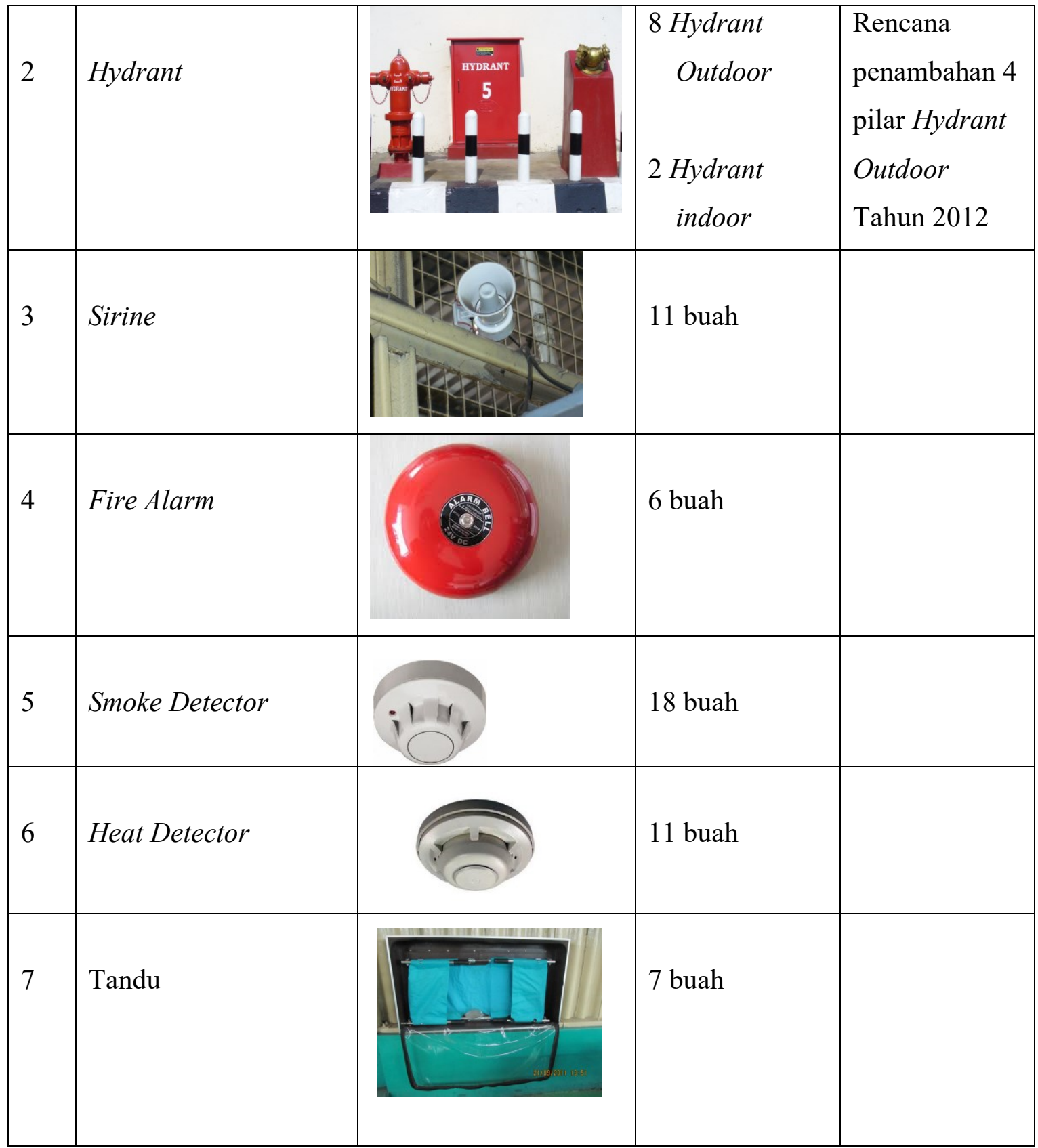

Sumber: Dokumen P2K3 PT Yuasa Battery Indonesia

\section{Identifikasi Bahaya}

Identifikasi bahaya dikelompokkan menjadi 3 yaitu: operasi, pemeliharaan, dan HSE.

1. Operasi

Kegiatan yang menimbulkan resiko bagi keselamatan dan kesehatan kerja adalah kegiatan :

a. Menyelupkan pelat kedalam air yang terdapat aliran listrik dapat menyebabkan kematian karena tersetrum pada tegangan yang cukup tinggi. 
b. Proses pembuatan rangka pelat yang membutuhkan ekstra hati-hati karena suhu yang sangat tinggi $400^{\circ} \mathrm{C}$, jika pekerjanya tidak memakai sarung tangan katun dan sarung tangan karet akan sangat bahaya resikonya dapat melepuhkan tangan, luka bakar yang serius, bahkan kematian.

c. Di tempat penyetruman untuk aki basah terdapat bahan kimia, kegiatan ini juga dapat menimbulkan risiko kecelakaan kerja karena terpercik bahan kimia yang menyebabkan luka ataupun kematian.

d. Proses pemotongan pelat accu dapat menyebabkan cacat pada para pekerja ataupun kematian.

\section{Pemeliharaan}

a. Melaksanakan persiapan kegiatan las yang dapat menimbulkan resiko terjadinya kebakaran karena percikan api yang dapat menyebabkan luka bakar dan adanya uap metal yang dapat menyebabkan iritasi.

b. Peleburan timah yang dapat menimbulkan resiko terjadinya kecelakaan yang disebabkan karena api yang dapat menyambar.

c. Tumpahan bahan B3 dan limbah cair yang dapat mengakibatkan luka bakar dan kematian.

d. Dalam menyelupkan pelat kedalam air yang terdapat aliran listrik, dapat menyebabkan resiko kematian.

\section{Health, Safety, and Environment}

Persiapan dan inspeksi lapangan, kegiatan ini dapat menimbulkan resiko kecelakaan terpeleset akibat bahan kimia yang menyebabkan luka memar hingga kematian.

Dari identifikasi bahaya yang dilakukan perusahaan, maka diketahui bahwa potensi terjadinya kecelakaan kerja adalah pada kegiatan pemeliharaan dan operasi yang disebabkan karena kelalaian yang mungkin dilakukan oleh pihak pekerja ataupun operator yang diduga dapat menyebabkan kecelakaan kerja pekerja itu sendiri dan merugikan perusahaan.

\section{Pengendalian Risiko Kecelakaan Kerja}

Fasilitas operasi produksi ini didesain sedemikian rupa untuk mengurangi dampak fatal yang dapat terjadi pada saat pekerjaan berlangsung. Identifikasi risiko yang telah dilakukan lalu dilanjutkan dengan penilaian besaran resiko dan ditetapkan pula 
pengendalian yang disesuaikan dengan standar dan peraturan yang berlaku. Pengendalian resiko kecelakaan kerja dilakukan dengan :

1. Training Tata Kerja Individual untuk operator,

2. Penggunaan APD (Alat Pelindung Diri),

3. Pelatihan tanggap darurat ledakan dan kebakaran atau ERP (Emergency Response Procedure),

\section{Alat Pelindung Diri}

Seluruh pekerja/karyawan perusahaan melakukan aktivitas kerja di unit produksi dan juga para tamu yang berkunjung harus menggunakan alat pelindung diri yang sesuai dengan peraturan. Peralatan pelindung diri disediakan oleh PT. Yuasa Battery Indonesia baik untuk tamu maupun pekerja. Jika tamu ke lapangan maka tamu akan diberikan masker dan topi. Penggunaan alat pelindung diri diatur dalam TKO B-04/EP 1201/2008SO tentang alat pelindung diri.

1. Masker Chemical Respirator NP 305 untuk meminimalisir paparan B3 yang digunakan dalam proses produksi.

2. Safety Glasses ANSI Z87+ digunakan pada saat pekerjaan pengelasan untuk melindungi mata dari panas atau sinar yang berlebihan.

3. Safety Shoes ANZI Z41 digunakan pekerja dan tamu selama berkunjung atau melakukan aktifitas kerja di unit produksi.

4. Chemical Gloves Petrohek Polivinyl Chloride 12-254 ANSELL ED Mant.10 digunakan oleh pekerja untuk membersihkan dan proses pemindahan limbah B3 ke gudang B3 di CO2 Removal Plant Subang atau untuk pekerja yang berhubungan dengan penggunaan bahan kimia berbahaya.

5. Ear Plug ULTRA FIT digunakan oleh para pekerja maupun tamu yang bekerja maupun berkunjung ke unit produksi yang diduga akan menimbulkan gangguan pendengaran karena adanya paparan bising.

6. Tidak ada pakaian khusus yang dapat melindungi badan untuk para pekerja, hanya perbedaannya terlihat dari pakaian lapangan, pakaian lapangan harus digunakan pekerja saat memasuki unit produksi untuk menghindari kecelakaan kerja (misalnya terkena tumpahan bahan kimia atau B3) dan disiplin pekerja. Pakaian lapangan yang digunakan terbuat dari bahan kanvas sorot lampu mobil pada malam hari, hal ini ditujukan guna menghindari kecelakaan pada pekerja karena tertabrak mobil pada malam hari. 


\section{Penanganan dan Penanggulangan Bahaya Kebakaran/Keadaan Darurat.}

PT. Yuasa Battery Indonesia telah membentuk tim penanggulangan bahaya kebakaran/keadaan darurat berdasarkan tentang kesigapan dan penanggulangan keadaan darurat, tim yang dibentuk adapun sebagai berikut :

\section{Komite PPK (Penanggulangan dan Pencegahan Kebakaran)}

a. Membuat pedoman prosedur dalam pelaksanaan kesiagaan dan tanggap darurat kebakaran yang terjadi di tempat kerja.

b. Menyiapkan dan mengalokasikan alat pemadam kebakaran di setiap lokasi dan mesin produksi yang teridentifikasi berpotensi menimbulkan kebakaran, sesuai dengan tipe alat pemadam kebakaran.

c. Merencanakan dan mengusulkan sistem pencegahan, peringatan dini dan sistem komunikasi dan evakuasi.

d. Mengidentifikasi setiap bahan dan jenis mesin yang berpotensi menimbulkan kebakaran di setiap lokasi kerja.

e. Tanggap darurat meliputi langkah-langkah penanganan kebakaran, pelaporan, dan permintaan bantuan kepada pihak Pusat Pemadam Kebakaran Wilayah Kota Tangerang.

f. Membuat/menempelkan petunjuk jalur evakuasi dan penanganan evakuasi karyawan bila terjadi kebakaran.

g. Membuat tata cara pemakaian "APAR" dan ditempatkan/ditempelkan dekat alat pemadam di lokasi yang telah ditetapkan.

h. Menjadwalkan penggantian isi "APAR" sekaligus menyusun program pelatihan penggunaan alat pemadam kebakaran secara berkala.

i. Membuat tata cara/buku panduan penggunaan Hydrant serta merencanakan jadwal pelatihan secara periodik untuk tim tanggap darurat unit Kebakaran (Tim TACT).

j. Melakukan kegiatan simulasi tanggap darurat evakuasi karyawan saat kebakaran terjadi.

k. Menyampaikan laporan kegiatan kepada Ketua P2K3.

\section{Komite Evakuasi dan Komunikasi}

a. Menyusun rancangan system prosedur evakuasi karyawan di lingkungan pabrik.

b. Menetapkan jalur evakuasi sesuai lokasi kerja menuju lokasi yang telah ditetapakan (Titik Kumpul) oleh Tim P2K3. 
c. Membuat dan menempatkan informasi tertulis dan rambu-rambu evakuasi di lokasi dan di tempat yang strategis.

d. Memberikan informasi kepada pihak internal dan eksternal perusahaan sehubungan dengan terjadinya suatu keadaan yang mengakibatkan terjadinya tanggap daruat kebakaran, kebocoran gas B3, tumpahan bahan B3, dan limbah cair.

e. Membuat laporan secara tertulis mengenai situasi dan kondisi yang terkait dengan penyebab sebelum dan sesudah terjadinya suatu keadaan darurat.

f. Menyampaikan laporan kegiatan kepada Ketua P2K3.

Pelatihan tanggap darurat kebakaran secara keseluruhan yang mengakibatkan penanggulangan keadaan darurat kebakaran dan ledakan serta melibatkan seluruh karyawan yang dilakukan 6 bulan sekali.

\section{Sarana dan Pelayanan Kesehatan PT. Yuasa Battery Indonesia}

Sarana kesehatan yang diwujudkan oleh PT. Yuasa Battery Indonesia adalah :

1. Di setiap unit produksi Kotak P3K disediakan yang terdiri dari minyak angin, kassa, perban selotip, balsam, kapas, obat merah, dll.

2. Pengobatan tingkat I, merupakan peneliharaan kesehatan karyawan PT. Yuasa Battery Indonesia yang meliputi gangguan kesehatan dikarenakan adanya penyakit dan penanganan luka penyakit akibat kecelakaan kerja. Pengobatan tingkat I ini dilayani oleh Poliklinik perusahaan. Tim medis berjumlah 5 orang dan dokter perusahaan 2 orang yang bergantian praktek setiap harinya khusus melayani karyawan.

3. Pengobatan tingkat lanjutan, pengobatan ini ditujukan terhadap karyawan yang terkena kecelakaan pada saat bekerja yang tidak dapat ditangani lagi pada pengobatan tingkat I dikarenakan terbatasnya peralatan atau kurangnya tenaga spesialis dan professional. Rumah sakit rujukan untuk pengobatan tingkat lanjut sbb :

a. RS. Sari Asih, J1. Imam Bonjol No.38, Tangerang 15113.

b. RS. Usada Insani, Jl. K.H. Hasyim Ashari No.24, Tangerang.

c. RS. Mayapada, Jl. Honoris Raya Kav.6 Kota Modern-Tangerang.

d. RS. Awal Bros, J1. MH. Thamrin No.3, Kb Nanas, Cikokol-Tangerang.

e. RS. Qadr, Komp. Islamic Village, Tangerang 15001.

f. RS. Asshobirin, Jl. Raya Serpong, Pondok Jagung Tangerang.

g. RS. Pelabuhan Jakarta, J1. Kramat Raya No.01, Jakarta Utara.

h. RS. Islam Sukapura, Jl. Tipar Cakung No. 06 Sukapura, Jakarta Utara. 
i. Klinik Gunung Sindur, Jl. Pemuda Kampung, Kb. Kopi, Kec. Gn Sindur, Bogor.

j. Klinik Puti Handiyah, Jl. Raya Serpong, Serpong, Tangerang.

k. Klinik Diana Permata Medika, J1. MH. Thamrin, Tangerang.

1. Klinik Citra Husada, Jl. Dewi Sartika, Kota Tangerang.

\section{Analisa Data dan Hasil Analisa Data}

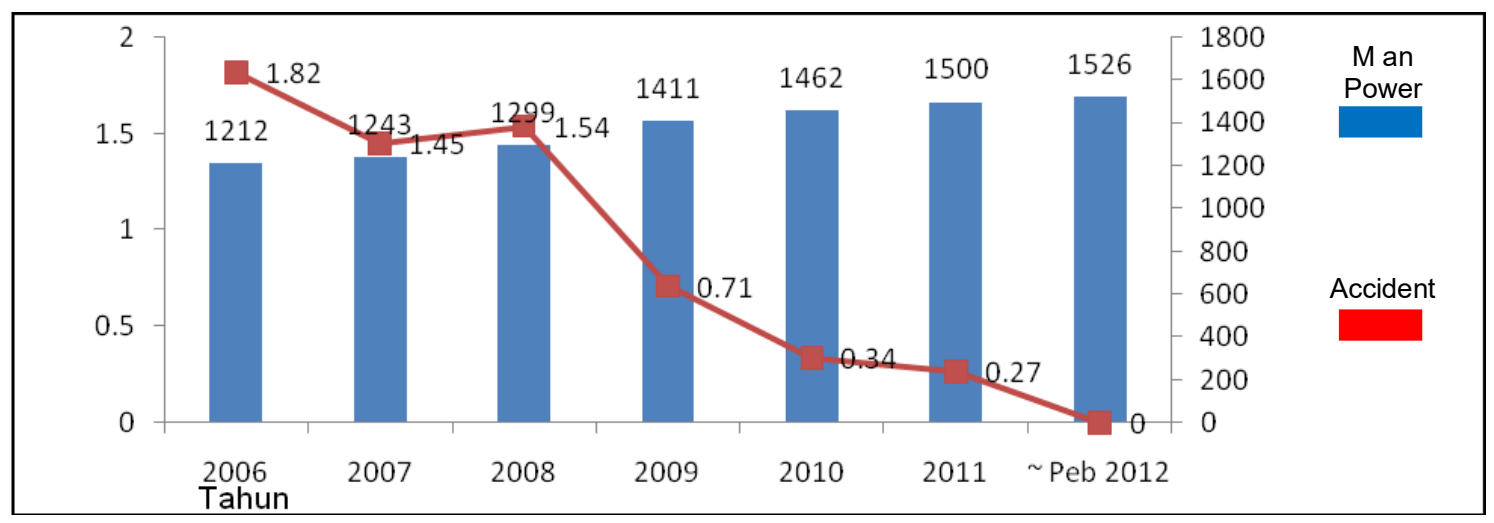

*Tahun 2010 mulai implementasi Sistem Keselamatan dan Kesehatan Kerja

Gambar 5. Data Statistik Kecelakaan Kerja PT. Yuasa Battery Indonesia Sumber: Dokumen P2K3 PT Yuasa Battery Indonesia

\section{Implementasi Sistem Keselamatan dan Kesehatan Kerja PT. Yuasa Battery Indonesia}

Untuk merealisasikan tujuan Sistem Keselamatan dan Kesehatan Kerja sesuai dengan UU No. 1 tahun 1970 yang mengatur tentang Keselamatan Kerja dan Peraturan Menteri Tenaga Kerja No. 05 tahun 1996 tentang Sistem Manajemen Keselamatan dan Kesehatan Kerja (SMK3), Pada akhir tahun 2009 dilakukan penyempurnaan Struktur Organisasi P2K3. Wujud dari dukungan Top Manajemen terhadap perlunya dilaksanakan Sistem Keselamatan dan Kesehatan Kerja tersebut bisa dilihat dengan dengan dikeluarkannya Surat Keputusan (SK) pembentukan susunan pengurus P2K3 (Panitia Pembina Keselamatan \& Kesehatan Kerja). ..(Lampiran 1)

Untuk menciptakan rasa aman dan nyaman pekerja serta upaya meminimalisir bahaya menghindari terjadinya kecelakaan kerja, P2K3 sebagai badan yang bertanggung jawab untuk hal tersebut membuat program kegiatan, seperti pengadaan alat tanggap darurat, identifikasi potensi dan sumber bahaya, serta sosialisasi penggunaan alat pelindung diri (APD) secara benar. 


\section{Pembahasan Hasil Analisa Data}

Dari data statistik di atas bisa dilihat sebelum impementasi Sistem Keselamatan dan Kesehatan Kerja, persentasi kecelakaan kerja di PT. Yuasa Battery Indonesia masih tinggi, penulis mengambil data dari tahun 2006 (1,82\%), 2007(1,45\%), 2008 (1,54\%), sebelum implementasi SMK3 atau rata-rata: 1,6 \%. Dan setelah implementasi SMK3 tahun $2009(0,71 \%), 2010(0,34 \%), 2011(0,27 \%), \sim$ Peb 2012(0 \%) atau rata-rata: 0,33 $\%$.

Jadi Implementasi Sistem Keselamatan dan Kesehatan Kerja cukup efektif untuk meminimalisir kecelakaan kerja PT. Yuasa Battery Indonesia.

\section{KESIMPULAN DAN SARAN}

\section{Kesimpulan}

1. PT. Yuasa Battery Indonesia.merupakan bagian dari Yuasa Group Companies, yang berkonsentrasi pada berbagai bidang, mulai dari berbagai jenis baterai/aki, rectifier, UPS dan produksi yang ada kaitannya dengan kendaraan.

2. Sebagai bentuk tanggung jawab perusahaan dan amanat UU No.1 tahun 1970 tentang Keselamatan Kerja, dan juga Per.05/Men/1996 tentang Sistem Manajemen Keselamatan dan Kesehatan Kerja, maka perusahaan berkomitmen melaksanakan Sistem Keselamatan dan Kesehatan Kerja agar pekerja merasa aman dan nyaman dalam bekerja, sehingga produktifitas akan meningkat dan asset perusahaan terlindungi.

3. Sebelum implementasi Sistem Keselamatan dan Kesehatan Kerja, angka kecelakaan kerja dinilai tinggi.

\section{Saran}

1. Perlu pengadaan springkler untuk di kantor maupun unit produksi, sehingga bilamana terjadi gejala dan atau kebakaran, secara otomatis bisa ditanggulangi.

2. Perlu adanya ahli K3 yang disahkan Instansi yang berwenang sebagai legalisasi tenaga terampil dalam Sistem Keselamatan dan Kesehatan erja

3. Jarak antara SPBU dengan lokasi pabrik yang bersebelahan, yang mungkin akan berdampak negatip/buruk akan potensi terjadinya kebakaran, perlu upaya koordinasi dengan pemilik SPBU, seperti pengadaan latihan bersama upaya pemadam kebakaran antara karyawan PT. Yuasa Battery Indonesia dengan karyawan SPBU. 


\section{DAFTAR PUSTAKA}

Silalahi Bennet dkk, 1995, Manajemen Kesehatan dan Kecelakaan Kerja, Sabdodadi, Jakarta.

Cohran, W.G.,1979, Sampling Technique. $3^{\text {rd }}$ Edition. New York: John Wiley \&Sons.

Levine, David M., Stephan David, Krehbiel Timothy C.\& Berensen, Mark L. 2002, Statistic for Managers Third Edition, New Jersey: Pearson Education Inc.

Deming, W.E., 1950, Some Theory of Sampling. New York: John Willey \& Sons.

Dokumen P2K3 PT. Yuasa Battery Indonesia

Meleong, Lexy J., 2001. Metodologi Penelitian Kualitatif. Bandung: Remaja Rosadakarya.

Noeng Muhajir. 2000. Metodologi Penelitian Kualitatif. Yogyakarta: Raka Serasin.

Somantri dan Sambas Ali Muhidin. 2006. Aplikasi Statistika dalam Penelitian. Bandung: Pustaka Setia.

Sulaksmono, 1997, Handout: Manajemen Keselamatan Kerja, Surabaya.

Suma'mur, 1987, Keselamatan Kerja dan Pencegahan Kecelakaan, CV Haji

Mas Agung, Jakarta.

www.google.com

www. wikipedia.org.id

www.yuasabattery.co.id

\section{LAMPIRAN}

\section{SURAT KEPUTUSAN}

No : 33/SK/YBI/V/2009

MENIMBANG $\quad: 1$. UU No.1 Tahun 1970 tentang Keselamatan Kerja.

2. Permenaker No. 05 Tahun 1996 tentang Sistem

Manajemen Keselamatan \& Kesehatan Kerja.

3. Tim Tanggap darurat Sistem manajemen Lingkungan ( ISO $14001: 2004$ ) 


\section{MEMUTUSKAN}

MENETAPKAN : SUSUNAN, TUGAS POKOK, FUNGSI, DAN KEGIA-

TAN P2K3 sebagai berikut :

1. SUSUNAN P2K3
1.1. Ketua
: S. Suparyono
1.2. Sekretaris
: Harjoyo

1.3. Komite Pertolongan Pertama Pada Kecelakaan ( P3K )

Ketua : Iman Suciyatno

1.3.1. Bagian Pertolongan Kecelakaan :

1. Ayub

2. Petugas Medical

1.3.2. Bagian Pencegahan, Komunikasi \& Informasi Kecelakaan :

1. Ponimin

2. Pengurus SPSI

1.3.3. Bagian Koordinator Pelaksana :

1. Semua Ka. Sub Sie / Ka. Sie

1.4. Komite Penanggulangan \& Pencegahan Kebakaran

Ketua : Surdi Nita Komara

1.4.1. Bagian Perlengkapan :

1. Achmad Fuad

2. Abdul Latif

1.4.2. Bagian Pencegahan \& Pengawasan :

1. Sukirman

1.4.3. Bagian Koordinator Pelaksana :

1. Semua Ka. Ru Keamanan

2. Semua Ka. Sub Sie / Ka. Sie

1.5. Komite Evakuasi \& Komunikasi

Ketua : Rohman HM.

1.5.1. Bagian Koordinator Pelaksana :

1. Semua Ka. Ru Keamanan

2. Semua Ka. Sub Sie . Ka. Sie 
1.6. Komite Penanggulangan \& Pengendalian Lingkungan

Ketua : : Lilik Tutuko R.

1.6.1. Bagian Pengendalian lingkungan :

1. sunarno

2. Hilman Muttaqien

1.6.2. Bagian Penanggulangan Teknis / Lingkungan :

1. Yani Winarto

2. Ruminto

1.6.3. Bagian Koordinator Pelaksana :

1. Semua Ka. Sub Sie / Ka. Sie

\section{TUGAS POKOK P2K3}

Tugas Pokok P2K3 sebagai suatu badan pertimbangan di tempat kerja yang memberikan Saran dan Pertimbangan baik diminta maupun tidak kepada Pengurus / Atasan terkait mengenai tempat kerja, masalah Keselamatan dan Kesehatan Kerja, serta pencegahan bahaya kebakaran.

\section{FUNGSI P2K3}

Fungsi P2K3 ialah menghimpun dan mengolah segala data dan atau permasalahan Keselamatan dan Kesehatan Kerja di tempat kerja serta mendorong ditingkatkannya penyuluhan, pengawasan, latihan dan penelitian Keselamatan dan Kesehatan Kerja.

4. KEGIATAN P2K3

KEGIATAN P2K3 meliputi :

1. Mengevaluasi sumber bahaya potensial yang ada di tempat kerja

1.1. Bangunan : Konstruksi, tata ruang, perawatan dll.

1.2. Alat Produksi : Alat mesin, pesawat, Instalasi dll.

1.3. Sistem Penanggulangan : Konstruksi, Instalasi \& peralatannya.

1.4. Proses Produksi : Dimulai dari awal sampai akhir.

1.5. Lingkungan Kerja : Sanitasi, air buangan, debu, gas, kebisingan, getaran, penerangan, iklim kerja dll.

1.6. Tenaga Kerja : Alat perlindungan dirinya, sikap dan cara kerjanya, disiplin kerjanya dll.

2. Pembinaan/Pendidikan yang ditujukan untuk seluruh Tenaga Kerja tentang : 
Dasar-dasar Keselamatan dan Kesehatan Kerja, Pencegahan Kecelakaan Kerja serta pencegahan/penanggulangan kebakaran.

Demikian Surat Keputusan ini dibuat, adapun hal-hal lain yang belum diatur akan diatur kemudian.

\author{
Ditetapkan di : Tangerang \\ Pada tanggal : 29 Nopember 2009 \\ PT. YUASA BATTERY INDONESIA \\ $\underline{\text { Ir. Hanifah Prawirakusuma }}$
}

